\title{
Investigating the Potentially Contradictory Microfoundations of Financialization
}

\author{
Matthew Watson \\ Department of Politics and International Studies \\ University of Warwick, UK
}

Published in Economy and Society, 38 (2) 2009, 255-277. 


\title{
Investigating the Potentially Contradictory Microfoundations of Financialization
}

\begin{abstract}
The existing academic literature on financialization points to multiple instances in which firms attempt to demonstrate the vitality of their stock market position in ways which ultimately prove to be self-harming. I demonstrate, in the first instance as a matter of immanent logic, that these actions are linked to the interplay of contradictory tendencies in the microfoundations of financialization. Under conditions of financialization, firms create additional sources of credit to capitalize their productive activities by driving their stock price into greater increases than the market average, thereby generating capital gains. Yet, the more it becomes public knowledge that the financing tricks used to inflate the stock price provide no productive benefit to the firm, the more that it would seem to create incentives for fund managers to hold portfolios that replicate the stock market as a whole. In this way, they will minimize their exposure to financial misrepresentation. Such a stance undermines financialized business models, but it does in any case conform to fund managers' basic theoretical training, which revolves around the logical demonstration that an individual stock cannot systematically out-perform the market average. I review the available empirical studies of fund manager decision-making to show that they find against the existence of a simple performativity loop operating between finance theory and fund manager behaviour. However, on many points the empirical evidence does confirm the theoretically-derived conclusion concerning the potentially contradictory microfoundations of financialization. Fund managers often do act in a way which is consistent with finance theory's core claim that an index-tracking strategy represents the only equilibrium portfolio, even if this is only rarely as a result of the direct performativity of the theory.
\end{abstract}

\section{Key Words}

financialization; microfoundations; fund managers; the Capital Asset Pricing Model; index-tracking; performativity. 


\section{Introduction}

The academic literature on financialization has tended to develop as a series of separate specialist arguments running in parallel rather than as an integrated whole. ${ }^{1}$ The result is a strong suggestion of quite distinct moments of socio-economic restructuring. An important task of future studies of financialization is to examine not only whether such moments cohere in their own terms, but also whether they are free of critical tendencies when considered as a single underlying shift in the social relations of production. The main conclusion to follow from this article is that individual parts of the political economy of financialization often work against one another. In particular, I argue that financialization is built upon potentially contradictory microfoundations, whereby the learned intuitions of fund managers serve to frustrate the attempts of corporate managers to introduce business models capable of enhancing shareholder value.

The modern state has an accumulation function due to the fact that the cohesion of society depends upon the health of the economy (e.g., Jessop 2007). In a financialized economy, the accumulation function passes directly through corporate managers' success in deriving additional shareholder value. This in turn depends on fund managers pushing the value of the financialized firm's stock price above that implied by changes in the market index. However, the accumulation function must always be balanced by a legitimation function (e.g., Carnoy 1984). Economic growth is not enough on its own to ensure social cohesion, as the distribution of growth dividends is also important. In a financialized economy, the legitimation function depends on the success of fund managers in investing passive savers' money for the future. By seeking to insure passive savers against unpredictable reductions in their 
wealth, fund managers have an incentive to adopt only market-conforming strategies. Yet, such strategies render ineffective all attempts by corporate managers to beat the market average by pursuing shareholder value business models. This appears to place the accumulation function directly at odds with the legitimation function in the microfoundations of financialization.

In order to reach such a conclusion, the analysis proceeds in three stages. In section one, I outline the main features of my argument. I begin with an abstract account of the contradictory dynamics, before moving on to illustrate a variety of empirically verifiable concrete forms that the contradiction imposes upon economic relations. Sections two and three are then used to deepen the analytical basis of the argument by matching the theoretical discussion with the available empirical evidence. I locate the primary tension impacting upon the firm in the need for corporate managers to persuade their counterparts in investment funds to systematically unlearn all the knowledge imparted through their theoretical training which tells them that no individual stock can consistently out-perform the market as a whole.

In section two, I show that the logic of firms' attempts to forcibly increase existing levels of shareholder value runs contrary to how fund managers are taught the basic tools of the money management trade. The contradictory microfoundations of financialization arise from a basic incommensurability between the two: the insights of William Sharpe's Capital Asset Pricing Model imply the generic futility of all attempts to demonstrate superior levels of shareholder value. In trying to persuade fund managers that their theoretically-derived intuitions are misplaced, firms are increasingly pushed towards strategies of self-harm merely as a short-term palliative for their shareholder value business models. Treating this as a purely theoretical 
issue, it is reasonable to assume a pristine performativity loop operating between finance theory and the financial economy. Such an assumption, however, depicts the stock trading system as a fundamentally asocial environment.

Empirical studies reveal a far greater social richness penetrating the process of fund manager decision-making. As a result, I use section three to subsequently re-set the discussion by paying extra attention to empirical studies which situate fund managers in social context. The evidence highlights the significance which is attached to constructing personal networks in order to facilitate socially embedded behaviour. Fund managers routinely make themselves available for the frequent oneto-one meetings requested by corporate managers to discuss their firm's prospects. In Sharpe's hypothetical world, this is a complete waste of time, because fund managers should be concerned merely with tracking the market index and not with individual firms' prospective performance, yet the meetings nonetheless occur (e.g., Rao and Sivakumar 1999). But to what effect?

The interesting conclusion to arise from section three concerns the contents of the one-to-one meetings. The fact that these meetings take place at all is a point against the theory, but the evidence showing what goes on within the meetings does not refute the theoretically-derived suggestion of the contradictory microfoundations of financialization. Whilst actual practice is predictably found to be much less clearcut than Sharpe's hypothetical world infers, on many points the available studies of fund manager decision-making in social context go a long way towards confirming the presence of the theoretical relationships. The identification of a strong performativity loop from the Capital Asset Pricing Model to a functioning financial economy remains an exaggerated abstraction of a much more complex reality. Nonetheless, the pressures arising from the context in which they operate do influence 
fund managers to act in a manner consistent with what their behaviour would be were it fully performed by finance theory. At least to an extent, then, fund managers do seem to inhabit the type of world described by the theory, even if it is not the theory alone bringing the world into existence. As a consequence, there remains mileage in continuing to explore what I here describe as the potentially contradictory microfoundations of financialization.

\section{The Tendencies and Counter-Tendencies of Financialization}

An important element of the theoretical literature on financialization focuses on governments' attempts to institute a finance-led growth regime (e.g., Aglietta 2000; Boyer 2000). The aim of such strategies is to harness public policy to incentives designed to incorporate new financing techniques for making credit increasingly available throughout the business economy. If successful, this drives growth as the credit is recycled as enhanced consumption possibilities for both the household sector (manifested in higher demand for everyday goods) and the corporate sector (manifested in higher demand for capital goods). This can be thought of as the macrofoundations of financialization.

My concerns in this article are rather different. They are with the microfoundations of financialization. In general, the existing literature on this particular issue divides in two.

(1) One part of the microfoundations literature focuses on firms' attempts to improve

their stock market standing by purchasing value-based management advice (e.g., 
Micklethwait and Wooldridge 1996). This relates to new techniques for controlling the company accounts in ways that appear to leave firms undervalued relative to their competitors in terms of their overall stock market capitalization. If successful, by enforcing the impression of structural undervaluation, firms can engineer significant boosts to their trend stock price. This in turn is likely to free up new sources of credit flowing from the capital market into business enterprises, hence enabling firms to expand their presence in product markets.

(2) The other part of the microfoundations literature focuses on individuals' attempts to secure additional future consumption by transposing current savings into a range of different financial investments with the potential for realizing capital gains (e.g., Martin 2002; Langley 2008). If successful, the long-term increase in portfolio wealth can subsequently be cashed in so that individuals can provide for themselves forms of asset-based welfare. The processes of financialization are thus increasingly embedded in the goal of privatizing responsibility for consumption in old age and necessarily tie individuals' future economic security to the success of firms' business models.

In other words, the microfoundations of financialization are located at the intersection of the household and the corporate economies. My argument in what follows is that an essential tension exists at this intersection: the satisfaction of firms' needs within the corporate economy undermines individuals' attempts to provide for themselves future economic security via asset-based welfare, whilst the satisfaction of individuals' needs within the household economy undermines firms' attempts to use the capital market in order to enhance their operating potentials. It is in this context 
that I set out to investigate - in the words of the article's title - the potentially contradictory microfoundations of financialization.

The tension I identify is rooted in broader trends of recent socio-economic restructuring, the most important of which is the embrace of the ideology of shareholder value. Shareholder value strategies have been promoted at two distinct levels: (1) as a means for firms to rationalize the reallocation of their own resources so that their productive activities are oriented primarily towards raising their profile on the capital market rather than the goods market (e.g., Froud et al. 2000; Lazonick and O'Sullivan 2000); and (2) as a means for governments to harness the flow of funds around the capital market as an automatic pilot for social relations of production which facilitate the shift towards a system of asset-based welfare (e.g., Aglietta 2000; Boyer 2000). So, whatever tension is manifested in the microfoundations of financialization has implications not only for the way in which passive savers' money is invested on their behalf. It goes right to the heart of the viability of contemporary national accumulation strategies which are based around the dynamics of the capital market, because these in turn are predicated on the ability to continually expand passive savers' paper wealth.

As a general rule, accumulation imperatives must always be balanced by legitimation imperatives if a state is to continue its function of successfully embedding the national economy (e.g., Habermas 1976; Poulantzas 1978; Offe 1985). Under the influence of shareholder value ideology, accumulation takes place within firms whose business models are increasingly incorporated into the day-to-day dynamics of the capital market. The stock price thus becomes both the capital market's commentary on the operation of the business model and an important internal ingredient of the business model's chance of success. As a consequence, 
accumulation imperatives revolve around the relationship between the firm and the capital market. The firm remains the essential unit of accumulation, but only in terms of its capacity to negotiate its way around the constraints of the capital market. In addition, the relationship between the firm and the capital market is now an increasingly important factor in securing popular consent for profits to be taken out of society. That relationship therefore also acts as the potential source of legitimation.

This is because of the increasing political salience of passive savers: those sections of the population of advanced industrialized countries whose disposable income is higher than their current consumption needs and who consequently have money to set aside to finance future consumption. The short-run temporal horizon of accumulation strategies under financialization is juxtaposed with the long-run temporal horizons of legitimation strategies. Firms require constant increases in their particular short-run stock prices relative to the market average to keep their business models functioning smoothly, whereas passive savers have a rather different interest. They need to feel secure in expectations that the overall value of the stock market will rise from its current level if they are to believe that their invested money will remain safe.

In general, this money is not invested actively by the individuals concerned, but is entrusted to fund managers who invest it on their behalf. Consent for shareholder value strategies is only likely to be forthcoming when those investments pay off. As a proportion of them will be equities based, the ability of firms to continue to post stock price increases therefore provides the material underpinning for the legitimation structure in which shareholder value strategies are situated. Much, then, rests on the relationship between company managers and fund managers - and much more than has been explored in the financialization literature thus far. In the 
presence of the potentially contradictory microfoundations of financialization identified here, shareholder value strategies will always struggle to balance the competing imperatives of accumulation and legitimation.

The tension arises in the information flows that allow fund managers to decide how best to invest their clients' savings. Firms provide the detailed company accounts that constitute the major part of these information flows, and they have had increasing success in co-opting ostensibly independent corporate watchdogs to sign off aggressively presented accounts (e.g., Ravenscroft and Williams 2005). The interests of firms operating financialized business models are thus satisfied by the use of innovative accounting techniques designed to provide instant 'good news' about the state of company finances. However, the interests of financialized firms and the interests of financialized individuals are not aligned in this respect. The more that profit announcements underpinned by aggressive accounting techniques are shown to be nothing other than artificial good news, the more that household savings are put at risk if they are invested in firms employing such techniques. This in turn creates greater incentives for fund managers to diversify their investments on behalf of their clients.

Fund managers will not have full information about which firms have company accounts that are a genuine representation of their long-term financial position and which firms have company accounts whose underlying message is primarily the result of manipulation via aggressive accounting techniques. Set in such a context, their greatest chance of immunizing their clients' investment portfolios from the full effects of corporate governance breakdowns is to avoid having large positions in any single firm. This is best achieved by diversifying portfolio holdings, but the ensuing equalization of demand for stocks across different companies prevents 
financialized firms from enjoying the credit windfalls that result from stock price boosterism.

Only a limited number of shares of a company's stock are available on the open market at any moment of time. If a firm can feed the market environment with incredibly positive information about itself then fund managers might think about concentrating their clients' holdings in a particular stock. At this point the constrained supply of that stock would push up its price and allow the firm to profit from new cash flows on the back of its retained stock holdings. Yet, all this depends on fund managers being presented with evidence of unusual circumstances, whereby one firm has either markedly better performance indicators or markedly better prospects than any other in its sector. This in turn transposes into commercial incentives for firms to produce deliberately distorted information about themselves in an attempt to enforce the impression that their financial vitality does indeed represent something out of the ordinary (e.g., Coffee 2006: 31-2; Frankel 2006: 61-3).

Such commercial interests manifest themselves in the temptation to create a wilfully duplicitous picture of the firm's dynamic financial position. In Lawrence Revsine's sugar-coated phrase (1991), it is all about 'selective financial misrepresentation'. Yet, widespread public knowledge of such practices in the wake of Enronitis serves only to provide greater incentives for fund managers to stick rigidly to diversifying their portfolios as widely as possible. Any attempts that firms make via creative accounting to persuade fund managers to renege on investment strategies requiring them to buy and hold the market as a whole ironically appear to make such strategies increasingly attractive to them.

Equally, if firms do not engage in such practices then they also have no way of securing their desired outcomes so long as fund managers see no reason to depart 
from the insights of their basic financial training. Fund managers receive pretty much the same training as one another via MBA programmes, and the teaching on those programmes is dominated by exposure to orthodox financial economics (e.g., Thrift 1998: 164). The models on which orthodox financial economics is based are all, to some degree, variations of efficient market models (Watson 2007: 63-90). In an efficient market, individual stock prices are unpredictable moving forwards in time, which means that those prices are likely to follow a random walk (e.g., Malkiel 1999). In the context of random walk dynamics, the only optimal stock portfolio is the market in its entirety. Market-conforming performance simply reinforces fund managers' instincts to diversify across the market, so firms must create the image of market-beating performance if their shareholder value strategies are to succeed, even if the knowledge of how they did so subsequently confirms to fund managers that they are always right to trust their instincts. Hence, firms are faced with a genuine dilemma, and this informs my claim about the potentially contradictory microfoundations of financialization.

Stated like this, the argument is very abstract. However, there is also a more concrete way of cutting into the issues under discussion. This is to begin with the question, 'why do firms go bad?'. In general, there are two types of answer that can be given to this question. The first is to say that only some firms engage in systematic corporate governance abuses and that these are the firms that are unlucky enough to be run by bad people. The second is to explore the possibility that all firms have the potential to follow a similar route whenever they are placed in contradictory environments. The latter is my preferred type of explanation.

Clearly, the evidence of firms going bad can be situated on a rather large sliding scale: raiding employees' pension funds, deliberately deceiving outside 
investors, manipulating earnings, authorizing false accounts, under-declaring tax liabilities, etc. In general, though, all such examples are consistent with the increasing prevalence of what Julie Froud and her co-authors (2000: 109) have described as 'value-skimming'. These are coping strategies designed to protect the short-term financial bottom-line in the interests of presenting stock market analysts with ostensibly positive information. Yet, they are founded on dubious economic and ethical practices which lack a credible rationale when viewed through the perspective of the long-term viability of the firm.

It has long been argued in the management studies literature that an overemphasis on the financial bottom-line distorts the calculations of corporate officials and detracts from their primary goal of securing their firms' economic future (e.g., Wolfe 1988). Under shareholder value strategies, the protection of the financial bottom-line has become the core feature of the business model. The focus of managers therefore becomes the current level of the stock price and little else. This single goal, whereby short-term priorities are allowed to all but exclude long-term priorities, propels firms utilizing shareholder value strategies to adopt many of the characteristics that Burkard Sievers (1999) attributes to the 'psychotic organization'. In other words, a pathological fixation ensues with at least maintaining the value of the company's stock market capitalization, whatever the associated costs.

Three types of activity are particularly worth mentioning in this respect, because each highlights the associated costs.

(1) The incorporation of asset-light balance sheets. In recent times, stock price increases have been strongly linked to increasingly debt-free company accounts, giving firms an inducement to divest themselves of large debt holdings (e.g., 
Reinstein and McMillan 2004). For firms which continue to own significant quantities of their own shares, this results in an important source of free cash flow. The culmination of such strategies is to be operating with what Michael Mauboussin and Bob Hiler (1999) have called a 'gravity-free balance sheet'. For, the debtless configuration of balance sheets of this nature provides a potentially endless source of free cash flows.

However, debts are only usually taken onto the accounts in the first place in order to finance new investments which might protect existing product market share. Ridding the company accounts of debts is therefore often the same as selling off assets, but assets will only be built up initially if they have some productive potential. This situation is compounded if the assets being sold in the interests of short-term stock boosterism are essential plant and machinery which then have to be hired back at market rates. In these situations, production costs rise, with subsequent adverse implications for firms' ability to retain their long-term presence on product markets. Such firms will become increasingly unable to assist the long-term expansion of overall stock market valuation which is required to keep passive savers' money safe and to provide legitimation for ongoing processes of financialization.

(2) Share Buy-Backs. The aim here is to target increases in the figure for firms' earnings per share (e.g., Kennedy 2000: 59-60). This does not necessarily require an increase in earnings themselves, because share repurchases retire a proportion of the outstanding common stock of the company in question. As such, all firms have to do to increase both their earnings-per-share figure and their stock price is to ensure that their earnings do not fall by a greater percentage than that of the common stock it is able to buy back on the open market. 
However, diverting the company's resources towards share repurchases clearly diverts them away from its other spheres of operation. As the bull run of the 1990s reached its height as much of the available resources of publicly listed companies in the US and UK was being used on stock market activity to artificially boost the stock price as it was on basic research and development expenditure (Lazonick and O’Sullivan 2000). The opportunity cost of share repurchases therefore seems to be restricted long-term product market potential. Once again, the implication is that such firms eventually come to contribute little to the long-term legitimation of the processes of financialization. Indeed, they might actually serve to undermine the sense of legitimacy if their difficulties in retaining product market share translate into the perception that the stock market ultimately destroys passive savers' money.

(3) Aggressive Accounting Techniques. It is usual for firms who are engaged in attempts to inflate their shareholder value to use innovative mark-to-market and markto-model accounting in order to put a positive spin on their earnings positions (e.g., Fusaro and Miller 2002: 13-18; Elliott and Schroth 2002: 40-1). Under such a system, the value of assets is reassessed at the end of each quarter so that a 'fair value' price can be recorded for all assets which takes into consideration the fact that their resale price is likely to change over time (Revsine 2002: 141-2). Often these assets will be complex derivative instruments designed to securitize firms’ future earnings streams.

This means that accountants are constantly being put in a position in which they have to make a judgement call about how best to record future earnings from dynamic asset prices. Yet, they often do so under pressure of being told that they will lose their business if they do not present the types of figure that the company is 
looking for in its accounts (e.g., McLean and Elkind 2003: 39-42, 127-8). This gives firms, in effect, a degree of discretion in the presentation of their own accounts: the reporting entity’s finance department has significant latitude to establish what counts as ‘reasonable’ estimate parameters (Benston and Hartgraves 2002: 115). Nothing here is strictly illegal, but over-attention to lining up corporate activities with the best possible estimate parameters is once again usually detrimental to protecting long-term product market share. As such, the capacity to incorporate passive savers into the financialized structure will be as impaired as in the previous examples.

These self-harming strategies can be criticized in their own terms. However, they arise for a reason, which means that it is necessary to say more about their origins. From the perspective of this article, they should be understood as counter-tendencies linked to the tendency for fund managers to be sceptical of firms' attempts to induce market-beating increases in their stock price. I turn in the following section to assess the origins of such scepticism. I do so by examining the theoretically-derived professional habits of the fund managers who mediate the relationship between household savings and the potential success of shareholder value strategies.

\section{Portfolio Diversification and the Capital Asset Pricing Model}

Extremely few ordinary savers trust themselves to make their own investment decisions (Gourevitch and Shinn 2005). Instead, the flow of capital into the stock market is mediated by fund managers acting simultaneously on behalf of many passive savers. Fund managers typically shun the idea of channelling the savings that 
are placed in their hands into a small number of investments: the reluctance to concentrate portfolio wealth results from the fear of being vulnerable to a sectorspecific shock to the market.

The need to engage in portfolio diversification is fully specified within the field of financial economics. The seminal contribution to this style of thinking is William Sharpe's development of the Capital Asset Pricing Model (Sharpe 1963). Tracing the influence of the approach forward in time, we find that it underpins the assumptions from which the 'normal science problems' that still dominate finance theory have been constructed by subsequent generations of economists (MacKenzie 2006: 51). Moreover, for fund managers, the demonstration of professional credibility is tied to their willingness to act to some degree on Sharpe's central, albeit contentious, suggestion. His whole approach revolves around the core claim that rational portfolio management has nothing to do with in-depth knowledge of company-specific factors in the constitution of the portfolio.

The assumption of rationality embedded in this view arises from the fact that the aggregate value of the portfolio at any given moment of time will almost exclusively reflect the level at which the stock market index is trading (e.g., Malkiel 1999). Around $90 \%$ of the variability of a portfolio's overall value is unconnected with factors that relate solely to the individual stocks contained within the portfolio. Instead, it is explained by the impact on stock prices triggered by broader price movements in the stock market index. Harry Markowitz (1959) had previously demonstrated that diversified stock portfolios contained less intrinsic depreciation risk than concentrating the same volume of savings in a single stock. Sharpe extended Markowitz's analysis to suggest that there was no end to the efficiency gains that could be made through diversification. From the perspective of the Capital Asset 
Pricing Model, the optimal portfolio is to be invested evenly across the stock market as a whole relative to each stock’s weighting in the market index (Sharpe 1970).

No other outcome is possible given the mathematical models through which the fund managers will have learned their financial economics. According to the principles of differential calculus, minimizing the depreciation risk of the portfolio as a whole occurs when the variance in individual stock price movements exactly cancel one another out (Markowitz 1952: 78-9). In such circumstances, investors still experience depreciation risk on their individual stocks, but the short-run depreciation risk of their suitably diversified portfolio is zero (Tobin 1958: 71). James Tobin referred to this as the 'super-efficient portfolio'.

Sharpe's proposition was that, under these conditions, any attempt to adopt a super-efficient portfolio that was only selectively diversified necessarily led to behaviour which was out of equilibrium. This was due to the overbearing, but individually random, influence that the stock market index has on the price of particular stocks (e.g., Bernstein 1992). Selectively diversified portfolios cannot eliminate the random element of that influence and, therefore, choosing such a portfolio cannot be an optimizing strategy. The goal must be to eradicate the disequilibrium aspects of choosing individual stocks from within the overall market of potential stock purchases in circumstances in which price trends of the market as a whole affect the price trends of individual stocks. Using more complex mathematics than Markowitz, Sharpe was able to show that this desirable situation arises only when investors choose to buy and hold the entire market. In other words, the random character of the influence of the market index on individual stock prices can only be eliminated when the investor is exposed to every stock which comprises that index in proportion to their individual capitalization. According to the Capital Asset Pricing 
Model, no portfolio other than the entire market results in investors being able to hold the super-efficient portfolio (e.g., Mehrling 2005: 56).

It is fairly straightforward to hold a super-efficient portfolio nowadays. Advances in options pricing theory and associated developments in computer technology have made it possible to calculate the value at which to price synthetic assets traded against the level of the stock market as a whole (e.g., MacKenzie 2006: 143-77). Investment companies now routinely employ 'quants' - quantitative analysts trained not in economics but in physics or in mathematics - to handle the statistical computations required to pinpoint the precise characteristics at which to trade multiple stock index options in order to exactly balance the underlying portfolio of stocks in line with the insights of the Capital Asset Pricing Model (see Derman 2004). It is a well known finding of options pricing theory that there exists a unique combination of stock index options and cash which enables the investor to hold a synthetic position whose economic characteristics directly replicate those associated with the underlying index. The investor attempting to apply the teachings of the Capital Asset Pricing Model need not engage in a continual struggle to rebalance a portfolio containing every individual stock in the market following each change in relative prices. All that is necessary is to rebalance the synthetic position between cash and stock market index options when the level of the latter changes.

A whole range of new investment instruments has been introduced which go a long way towards 'completing' the stock market structure: i.e., closing the gaps between the markets for individual stocks by creating more precise economic links between them. But they also have another very important effect. Such is the volume of turnover today in index options that it has structurally reinforced the relationship that the introduction of index options was originally meant to reflect: the relationship 
between the level of the index and the price of individual stocks. If the latter had always been influenced by the former via the underlying 'mood of the market', that influence has now been irrevocably locked-in due to the ease with which fund managers can now load up their portfolios with index options. The introduction of new stock derivatives thus activates a performativity loop through which the impact of the market index on individual stock prices becomes ever more accentuated. In turn, the same performativity loop means that the insights of the Capital Asset Pricing Model become ever more compelling for those whose learned intuitions are in any case instinctively to adopt them.

In effect, the trade in index options has closed the gaps between the pricing structures of different stocks. There is no intrinsic economic link via the productive economy between the stocks of any two given companies, because those stocks relate to independent corporate entities. But there is now a financial link through the trade in index options which ensures that it is highly likely that the changes in stock market valuation between any two given companies on a particular day will be correlated. Indeed, the correlation in price changes between the stocks of any two companies will be replicated for all stock pairs across the entire market. By creating this complex web of links between individual stock prices, the trade in index options has created what in other circumstances Donald MacKenzie (2006) has described as a 'superportfolio' out of the market as a whole. That is, the stock prices of individual companies are now serially correlated with respect to one another. Tobin's superefficient portfolio and MacKenzie's super-portfolio are now therefore one and the same thing: the outcome of recent periods of innovation in tradeable financial instruments ensures that both relate to the market as a whole. 
The ready availability of index options means that investors can fully incorporate the insights of Sharpe's analysis into their activities, thus guaranteeing that they do no worse than make market average returns whilst minimizing the overall depreciation risks associated with their use of clients' money. For fund managers whose performance is evaluated against their ability to meet the market average on a quarter-by-quarter basis, this appears to be the ideal trading strategy. The Capital Asset Pricing Model is thus likely to loom extremely large in the calculations of fund managers, for whom failure to immunize their clients' savings by holding inadequately diversified portfolios appears somewhat reckless. Derivative markets now cover all possible types of synthetic assets in order to allow immunizing trades to take place (Steinherr 2000: 147-68). Now that this knowledge is widespread, it acts as some sort of totem for the trading strategies of fund managers in search of a suitable benchmark to target.

So, what can we take from Sharpe's analysis for current purposes? Perhaps most significantly, it appears from his perspective as though contemporary shareholder value strategies fail an important test of internal coherence. If shareholder value strategies are to be successful, then management consultants must generate purchasers for their services by showing how the companies they advise have experienced recent stock price increases in excess of the increase in the market index (Froud et al. 2000: 90). However, from the investor's point of view, it makes no sense for the company to spend its hard-earned cash purchasing the consultants' product. If the Capital Asset Pricing Model is to be believed, it does not matter to the investor - or, by implication, to passive savers - whether a company has bought some high-priced advice about how to enhance shareholder value. The stock of that company, taken on its own, should be no more attractive after the advice has been 
imparted than it was before. Despite the performance claims of the management consultants to the contrary, it is no more rational for fund managers to concentrate investments in firms that have invested in high-priced management advice than to concentrate them elsewhere. According to the central model of financial economics, asset concentration is to be avoided in all its forms, no matter how or in what sort of companies they are concentrated. If the stock market as a whole is the optimal portfolio before companies submit themselves to the advice of the shareholder value consultants, then it remains the optimal portfolio irrespective of the changes that any single firm introduces to its business model on the basis of management consultant advice.

The following, then, is the finding from financial economics: shareholder value strategies cannot work in their own terms. Fund managers who have been schooled in the insights of the Capital Asset Pricing Model can be expected to see through what will appear to their learned intuitions to be the illusory promises of the shareholder value consultants. Instead, they will settle for continuing to invest in diversified portfolios which act against the consultants’ hopes that their clients' stock will feature more prominently in the funds' holdings. It would appear as though the serial correlation of individual stock prices arising from the trade in stock derivatives leaves them with no viable alternative.

\section{Explaining Fund Manager Practice}

The tension I identify in the microfoundations of financialization depends on the existence of a strong performativity loop through which financial theory enacts the 
trading strategies which drive the financial economy on a day-by-day basis (e.g., Callon 1998). This is implied as a matter of logic, but it is a bold claim to make in relation to actual practice (e.g., Abolafia 1996; Shiller 2000; Sassen 2005). It depicts fund managers as little more than bearers of the structural effects established by the dominant models of financial theory.

Perhaps unsurprisingly, the empirical evidence on the dynamics of fund manager decision-making does precious little to sustain the image of completely socially abstracted behaviour. It suggests that the valuation of shares is at least partly a social phenomenon, insofar as network participation creates the necessary 'feel' for the market which then conditions subsequent behaviour. In Sharpe’s Capital Asset Pricing Model, anonymity in stock trading is no impediment to investors acting upon optimizing strategies. In fact, it might even assist in the process of maintaining portfolio equilibrium, because it keeps potentially ‘unhelpful' social influences at bay. To cope with the demands of Sharpe's hypothetical world requires only that investors interact in a perfunctory manner with numerical data relating to movements in the market index. Trading software is beginning to come on-stream which reduces the trading function simply to a process of shape recognition on computer screens, whereby what the trader sees in the shapes is a visual representation of changes in numerical market data (e.g., Pryke 2007). It is most unlikely, though, that this will ever fully substitute for the interpersonal experiences through which investors divine clues about what to buy and what to sell.

The reality of stock trading is hardly ever an anonymous process. Positioning oneself relative to market pricing trends is almost always mediated by prior contact with other people. To cope with the demands of the actual practice of stock trading therefore requires something quite different to what is implied by the Capital Asset 
Pricing Model. It involves assessing the always changing mood of the market, where in this case 'the market' is nothing more than the opinions of the fellow traders who comprise it. By necessity, then, if they are to get any sense of likely price changes fund managers must situate themselves in a much socially richer context than Sharpe’s hypothetical world (e.g., Knorr Cetina 2005).

Considerable effort is expended by both parties to the microfoundations of financialization - fund managers on the one hand and corporate managers on the other - in an attempt to finesse that context to their own advantage. Post-tech stock crash and post-Enron, the legal environment in which US and UK fund managers operate has changed, reflecting a rather greater political commitment to ensuring oversight of the way that passive savers' money is invested on their behalf (e.g., Thornburg and Roberts 2008). They are subjected to more intense scrutiny of their diligence at safeguarding the value of that money. For this reason, fund managers have willingly acquiesced to requests for meetings with corporate managers, because this is an important means of demonstrating due diligence (e.g., ISC 2002). However, it is significant that in general they are not the instigators of those meetings. This suggests that it is the corporate managers who believe that they have most to gain from initiating closer network relationships with fund managers.

In a recent qualitative study of firms' approach to the question of investor relations, Aeron Davis (2006: 8) has shown the lengths to which corporate managers are prepared to go in order to keep their firm - and its stock price - in the minds of fund managers. "All quoted companies, and their advisors, were aware of who their major shareholders and assessors were, and maintained high levels of communication with them.” In the US and the UK at least, the process of guiding investor relations has become big business in its own right. Both countries now have a professional 
association providing oversight of key investor relations' functions, as well as collecting data on best practice to allow firms to match themselves against the most impressive performance indicators in the field (e.g., Marston 1996: 479).

The most authoritative full-scale UK survey was performed by the Investor Relations Society in 1998. It showed that more than three-quarters of UK chief executive officers organized on an annual basis at least a dozen one-to-one meetings with fund managers to present the case for their firms to be included in the funds' portfolios. One-in-ten chief executive officers reported spending up to one-third of their time solely on trying to fashion advantageous relations with investors (IRS 1998).

On the basis of these statistics alone, we can conclude that corporate managers' perceptions of their everyday working environment are outwardly very different to those of the Capital Asset Pricing Model. There is no assumption on their part that they exist in Sharpe's hypothetical world. If there was, it would be an indelible part of their intuitive understanding of their environment that they were entirely powerless to alter the way in which their companies' prevailing stock price was received. Within the world of the Capital Asset Pricing Model, all decisions to buy and sell stocks take place relative to movements in the overall market index, not relative to news about likely company performance. All such news is rendered entirely inconsequential by Sharpe's assumptions about portfolio equilibrium (e.g., Mehrling 2005). Set against such assumptions, the verifiable presence of extensive strategies of active management of investor relations is a significant finding. It appears very much to create an unbridgeable gap between Sharpe's hypothetical world and actual practice: the active management of investor relations is all about 
trying to discriminate one firm from another in precisely the manner that the Capital Asset Pricing Model suggests is futile.

Discrimination techniques are by no means new or confined to the one-to-one meetings that corporate managers organize with fund managers. The whole ethos of public disclosure in the accounts and auditing process is intended to provide a way for investors to spot potentially stock price-sensitive differences between the ongoing financial positions of one company and every other (e.g., Trinkhaus and Giacalone 2005). The numerical nature of the accounts and auditing process offers investors a relatively straightforward means of ranking companies one against another. The significance of the one-to-one meetings is that they emphasize the interpersonal nature of investor relations in a manner which public disclosure data does not.

The very fact that corporate managers feel obliged to put themselves personally 'on show' for fund managers demonstrates the importance they attribute to the social networks which are the back story to most stock trading decisions. Whilst public disclosure of accounts and auditing data only allows for the vicarious observation of 'distant others', one-to-one meetings with corporate managers enable fund managers to engage in direct observations of a highly personalized nature (e.g., Roberts 2001). Companies with historically high beta shares (i.e., a greater than average variance in their stock price) have been most assiduous in attempting to foster compliant social networks (Marston 1996: 485). It is their managers, therefore, who submit themselves most routinely to direct observations.

In contrast to the largely non-socialized behavioural characteristics associated with performativity loops, the presence of active investor relations tends to personalize - perhaps even over-personalize - fund managers' perceptions of companies. As John Roberts and his co-authors suggest (2006: 286, emphasis added): 
"Face-to-face meetings ensure that the qualities of the message and the messengers become inextricably and consequentially entwined ... Individual executives, albeit the most senior managers, here stand in for - literally represent - the company”. The empirical evidence suggests that potential investors take the most positive impressions from one-to-one meetings in which corporate managers make the case that the company remains 'on track' as a direct reflection of their own personal management psyche. Fund managers look for a management style which exerts a tight grip on dayto-day activities, clamping down on any evidence of excessive perks which might divert company personnel from concentrating solely on achieving the firm's longterm objectives. The British Venture Capital Association has gone as far as to draw up a 'signs of frivolity' checklist in an attempt to highlight the personal traits in managers that investors should seek to avoid (Nisbet 1994: 147). Corporate managers therefore engage in sometimes quite conspicuous processes of self-disciplining simply to prepare themselves to act and to look the right way.

The emphasis on the personal dimension in empirical studies of the stock trading system appears to take the argument quite some distance from where it was situated in the opening two sections. Yet, before I rush to judgement and condemn my own perspective, a little further analysis is still in order. As is so often the case, the devil is in the detail here. The available empirical evidence is certainly strongly suggestive of the fact that fund managers do not inhabit Sharpe’s purely hypothetical world. However, the substantive dynamics of one-to-one meetings between corporate managers and fund managers do to some degree push in the general direction of a world constructed in the image of the Capital Asset Pricing Model. Four issues can usefully be highlighted in this respect to show that there is still life in the identification of the potentially contradictory microfoundations of financialization. I 
close by reviewing these four cases in turn. Significantly, each of them is drawn from the empirical literature which might otherwise be read as evidence against the perspective I develop in the opening two sections.

(1) The empirical literature charting the influences on fund manager decision-making revolves, at its core, around the question of whether or not a systematic approach to one-to-one meetings with corporate managers helps to make the stock market more efficient (e.g., Holland 2002). The rationale for asking such a question is itself drawn from modern finance theory, in particular its assumption that the relationship on any given day between an individual stock price and the market index is governed by the amount of information which is factored into investors' calculations of the stock's real worth (Bernstein 1992). An efficiently priced market is therefore an informationallyefficient market (e.g., Samuelson 1965: 41; Fama 1991: 1575).

In general, the empirical literature concludes that active management of investor relations does indeed enhance market efficiency (e.g., Barker 1998; Holland and Doran 1998). Yet, it is an efficient market which conditions the need to possess the equilibrium portfolio of fully diversified stock holdings in Sharpe's hypothetical world. Ironically, then, the more that one-to-one meetings between corporate managers and fund managers feed the stock market environment with information, the less operative that information is likely to become as a means of valuing individual stocks. This is because the gains in market efficiency will make it progressively harder for any selectively diversified portfolio to out-perform a weighted average of the market index. In such circumstances, the incentive is to act as if the real world was indeed Sharpe's hypothetical world and to construct a fully diversified portfolio equivalent to holding the market as a whole. 
(2) Moreover, the practicalities of the meetings themselves emphasize concerns for market efficiency as an implicit normative goal. There is a clear power asymmetry in the organization of the meetings: corporate managers make appointments with fund managers and travel to see them, not the other way around; corporate managers are required to justify their actions to fund managers, not the other way around. Whilst companies will send their most senior executives to act on behalf of the firm, they usually find that they are presenting themselves to a much younger and more junior representative of the fund who has no practical experience of running a business. As empirical studies show, theoretical knowledge is typically substituted for practical knowledge in such circumstances, especially the theoretical knowledge which the juniors standing in for the fund managers have "gleaned through an MBA" (Roberts et al. 2006: 285). Whereas companies usually strive for continuity of representation at one-to-one meetings, the turnover is much higher from the funds' side, throwing back each new junior in attendance in lieu of the fund manager into ever greater reliance on theoretical knowledge.

The structure of teaching on MBA programmes is heavily oriented towards issues of market efficiency, especially those that are consistent with the Capital Asset Pricing Model (e.g., Thrift 1998: 164). For the top programmes that utilize the case study teaching method, the cases are organized specifically to demonstrate to students the virtues of portfolio diversification. When the juniors standing in for fund managers rely on theoretical knowledge in their dealings with corporate managers, it is these virtues which act as interpretive frameworks for what they are hearing. 
(3) The influence of theoretical knowledge is by no means a one-way street. Corporate managers are reflexive actors. If they learn from experience that their words will be interpreted through a theoretical lens prioritizing market efficiency, it is to be expected that they will adjust their presentational style to suit the most likely subsequent interpretation. In this way, theoretical knowledge penetrates the representation of the firm, as corporate managers bow to their subordinate status in one-to-one meetings and allow themselves to be disciplined by their perceptions of fund managers’ expectations (e.g., Rao and Sivakumar 1999).

The ensuing presentational style directly mirrors the dual focus which I suggest lies at the heart of the potentially contradictory microfoundations of financialization. On the one hand, the meetings are conducted under the guise of assumptions concerning the merits of full portfolio diversification. Yet, on the other hand, meaningful results can only ensue for the firm if corporate managers are able to persuade fund managers that they are exceptions to the rule. The aim in this respect is to highlight ongoing attempts to restructure the firm's business model in order to maximize shareholder value. On the back of their extensive primary research of investor relations, Roberts et al. write (2006: 289-90) of a palpable sense of corporate managers trying to reinvent their management priorities so that they can give off the impression of being living embodiments of concerns for shareholder value. However, this is clearly a juxtaposition of assuming market efficiency but believing that it is necessary to act contrary to the assumption.

(4) Fund managers have one certain means of avoiding being caught out by such a juxtaposition: this is to use the market index as a benchmark to guide their actions. The use of some sort of benchmark is now widespread. It reflects the incentives with 
which fund managers are faced to match their own performance with that of their contemporaries. Fund managers are subjected to routine scrutiny of their performance, where to retain their positions they must be able to show that they have done no worse than the performance of the average fund (e.g., Barber and Ghilarducci 1993: 288). That average in turn can be no higher than the average price change across the market as a whole. Any fund manager whose portfolio directly replicates the properties of the market index is therefore guaranteed to pass the frequent performance checks which dominate the industry, no matter what other fund managers are doing.

This helps to explain the growth of index-tracking funds since the 1980s. Such funds are a relatively easy sell to passive savers because they shun the concentration of high beta stocks. Their rise has triggered the development of other types of fund, notably the hedge fund, in an attempt to use alternative trading strategies to escape what has been described by Davis's respondents (2006: 12) as "the tyranny of the benchmarks". But the proliferation of index-tracking funds nonetheless serves to create conditions which appear to be entirely modelled on Sharpe’s hypothetical world.

\section{Conclusion}

Treating the issue purely theoretically, the microfoundations of financialization do indeed appear to be so tension-prone as to be outright contradictory. I am content that the logic of the preceding argument is sound, but it is only in extremely rare instances that an absence of inherent sociality means that there is a direct correspondence 
between immanent logic and actual practice. In the real world, the stock trading system is grounded in embedded social relations to an extent which is impossible to capture in a theoretical treatment which assumes a performative relationship between finance theory and the financial economy.

The identification of the contradictory microfoundations of financialization as outlined in the opening two sections relies on just such an assumption. This does not make the analysis wrong, but it does caution against expecting to find the same clarity of relationship in empirical studies. Sure enough, empirical treatments of the interaction between corporate managers and fund managers do indeed point to a much more socially rich working environment than is depicted in performativity theory. Yet, they do also point to important sources of evidence which are consistent with the implications of the purely theoretical discussion.

The remaining questions to resolve are ones of degree: precisely how much confirmation of the theoretical relationships are we talking about here, and is that confirmation getting stronger or weaker over time? Unfortunately, we are not yet in a position to know, and it is possible that we may never be. The necessary information is hard to come by, and there are in any case extremely few researchers working actively on large-scale qualitative studies of fund manager practice. It is also highly unlikely that such practice will remain as it was studied for long. The 'investment fund' is not a homogeneous category, so any attempt at the sort of generalization entered into here necessarily comes at the risk of losing sight of existing diversity in funds' trading strategies. New types of fund which have not even been contemplated today are also likely to become a reality in the future. The exact degree to which the theoretical relationships are actualized is unlikely to be stable over time: it will reflect the constant reinvention of the social relations of the stock trading system. 
However, this should not be seen as invalidating the purpose of the foregoing enquiry. There is much to be gained from analysing the potential contradictions of contemporary capitalism as a matter of logic, especially when partial confirmation is forthcoming for their practical manifestation. Whatever the broader social influences on actual trading decisions, the common-sense properties of financial models create a very real dilemma of financialization for firms. The successful operation of a financialized business model is entirely contingent upon fund managers ignoring the most fundamental insights of financial economics, but two significant contextual factors suggest that this will probably not be the case. The reality of investing passive savers' money means that fund managers are likely to internalize those savers' riskaversion, which immediately places them in a decision-making context analogous to the hypothetical world of the Capital Asset Pricing Model. The analogy is deepened when it is remembered that fund managers have to pass frequent performance checks which incentivize market-conforming trading strategies.

As such, the fact that an increasing number of firms are submitting themselves to financialized management techniques most likely means that they will be running business models which do not work in their own terms. There is much at stake, then, when it comes to discovering exactly how financial economics influences the investment decisions of fund managers. By no means the least of the things at stake are the savings of individuals who increasingly have to rely on asset-based systems of welfare to fund their consumption in old age. The long-term legitimation of financialization appears to depend, rather ironically, on fund managers activating the contradictions in financialized firms’ accumulation function. 


\section{Notes}

${ }^{1}$ This piece was written with the financial assistance of a grant from the UK's Economic and Social Research Council (number RES-000-22-2198). I gratefully acknowledge the ESRC's continuing support of my research. A very early first version was presented at the annual conferences of the British International Studies Association in December 2006 and the International Studies Association in 2007. I am grateful to the participants at those conferences, as well as to Economy and Society's anonymous referees, for the help they gave me in refining my argument.

\section{References}

Abolafia, Mitchel (1996) Making Markets: Opportunism and Restraint on Wall Street, Cambridge, MA: Harvard University Press.

Aglietta, Michel (2000) 'Shareholder value and corporate governance: some tricky questions', Economy and Society 29 (1): 146-159.

Barber, Randy and Ghilarducci, Teresa (1993) 'Pension funds, capital markets, and the economic future', in Gary Dymski, Gerald Epstein and Robert Pollin (eds.) Transforming the US Financial System: Equity and Efficiency for the $21^{\text {st }}$ Century, New York: M.E. Sharpe, pp. 287-320.

Barker, Richard (1998) 'The market for information - evidence from finance directors, analysts and fund managers', Accounting and Business Research 29 (1): 3-20.

Benston, George and Hartgraves, Al (2002) 'Enron: what happened and what we can learn from it’, Journal of Accounting and Public Policy 21 (2): 105-127.

Bernstein, Peter (1992) Capital Ideas: The Improbable Origins of Modern Wall Street, Hoboken, NJ: John Wiley and Sons. 
Boyer, Robert (2000) 'Is a finance-led growth regime a viable alternative to Fordism? A preliminary analysis’, Economy and Society 29 (1): 111-145.

Callon, Michel (1998) 'The embeddedness of economic markets in economics', in idem (ed.) The Laws of the Markets, Oxford: Blackwell, pp. 1-57.

Carnoy, Martin (1984) The State and Political Theory, Princeton, NJ: Princeton University Press.

Coffee, John (2006) Gatekeepers: The Professions and Corporate Governance, Oxford: Oxford University Press.

Davis, Aeron (2006) 'The limits of metrological performativity: valuing equities in the London Stock Exchange', Competition and Change 10 (1): 3-21.

Derman, Emanuel (2004) My Life as a Quant: Reflections on Physics and Finance, London: John Wiley and Sons.

Elliott, Larry and Schroth, Richard (2002) How Companies Lie: Why Enron is Just the Tip of the Iceberg, London: Nicholas Brealey Publishing.

Fama, Eugene (1991) 'Efficient capital markets: II', Journal of Finance 46 (5): $1575-1617$.

Frankel, Tamar (2006) Trust and Honesty: America's Business Culture at a Crossroad, Oxford: Oxford University Press.

Froud, Julie, Haslam, Colin, Johal, Sukhdev and Williams, Karel (2000) 'Shareholder value and financialization: consultancy promises, management moves’, Economy and Society 29 (1): 80-110.

Fusaro, Peter and Miller, Daniel (2002) What Went Wrong at Enron, Hoboken, NJ: John Wiley and Sons. 
Gourevitch, Peter and Shinn, James (2005) Political Power and Corporate Control: The New Global Politics of Corporate Governance, Princeton, NJ: Princeton University Press.

Habermas, Jürgen (1976) Legitimation Crisis, translated by Thomas McCarthy, London: Heinemann.

Holland, John (2002) 'Financial institutions' governance of the internal governance and value creation chain of companies - a grounded theory model', Department of Accounting and Finance Working Paper, No. 2002/5, University of Glasgow.

Holland, John and Doran, P. (1998) 'Financial institutions, private acquisition of corporate information, and fund management', European Journal of Finance 4 (2): 129-155.

Institutional Shareholders Committee (ISC) (2002) The Responsibilities of Institutional Shareholders and Agents: Statement of Principles, London: ISC.

Investor Relations Society (IRS) (1998) Investor Relations in the UK: Current Practices and Key Issues, London: Business Planning and Research.

Jessop, Bob (2007) State Power: A Strategic-Relational Approach, Cambridge: Polity.

Kennedy, Allan (2000) The End of Shareholder Value: The Real Effects of the Shareholder Value Phenomenon and the Crisis it is Bringing to Business, London: Orion.

Knorr Cetina, Karin (2005) 'How are global markets global? The architecture of a flow world', in Karin Knorr Cetina and Alex Preda (eds.) The Sociology of Financial Markets, Oxford: Oxford University Press, pp. 38-61.

Langley, Paul (2008) The Everyday Life of Global Finance: Saving and Borrowing in Anglo-America, Oxford: Oxford University Press. 
Lazonick, William and O’Sullivan, Mary (2000) 'Maximizing shareholder value: a new ideology for corporate governance', Economy and Society 29 (1): 13-35.

MacKenzie, Donald (2006) An Engine, Not a Camera: How Financial Models Shape Markets, Cambridge, MA: MIT Press.

Malkiel, Burton (1999) A Random Walk Down Wall Street, revised and updated edition, London: W. W. Norton and Company.

Markowitz, Harry (1952) ‘Portfolio selection’, Journal of Finance 7 (1): 77-91.

(1959) Portfolio Selection: Efficient Diversification of Investments, London: John Wiley and Sons.

Marston, Claire (1996) 'The organization of the investor relations function by large UK quoted companies’, Omega, International Journal of Management Science 24 (4): 477-488.

Martin, Randy (2002) Financialization of Daily Life, Philadelphia, PA: Temple University Press.

Mauboussin, Michael and Hiler, Bob (1999) Cashflow.com: Cash Economics in the New Economy, New York: Credit Suisse First Boston.

McLean, Bethany and Elkind, Peter (2003) The Smartest Guys in the Room: The Amazing Rise and Scandalous Fall of Enron, London: Viking.

Mehrling, Perry (2005) Fischer Black and the Revolutionary Idea of Finance, Chichester: John Wiley and Sons.

Micklethwait, John and Wooldridge, Adrian (1996) The Witch Doctors: What the Management Gurus are Saying, Why it Matters and How to Make Sense of It, London: Heinemann.

Nisbet, Michael (1994) 'Selecting the company’, Long Range Planning 27 (5): 145148. 
Offe, Claus (1985) Contradictions of the Welfare State, Cambridge, MA: MIT Press.

Poulantzas, Nicos (1978) State, Power, Socialism, London: New Left Books.

Pryke, Michael (2007) 'Money’s eyes: the visual preparation of financial markets', CRESC Working Paper Series, No. 42, Centre for Research on Socio-Cultural Change, Open University/University of Manchester.

Rao, Hayagreeva and Sivakumar, Kumar (1999) 'Institutional sources of boundary-spanning structures: the establishment of investor relations departments in the Fortune 500 Industrials’, Organization Science 10 (1): 27-42.

Ravenscroft, Sue and Williams, Paul (2005) 'Rules, rogues, and risk assessors: academic responses to Enron and other accounting scandals', European Accounting Review 14 (2): 363-372.

Reinstein, Alan and McMillan, Jeffrey (2004) 'The Enron debacle: more than a perfect storm', Critical Perspectives on Accounting 15 (6/7): 955-970.

Revsine, Lawrence (1991) 'The selective financial misrepresentation hypothesis', Accounting Horizons 5 (4): 16-27.

(2002) 'Enron: sad but inevitable', Journal of Accounting and Public Policy 21 (2): 137-145.

Roberts, John (2001) 'Trust and control in Anglo-American systems of corporate governance: the individualizing and socializing effects of processes of accountability’, Human Relations 54 (12): 1547-1572.

Roberts, John, Sanderson, Paul, Barker, Richard and Hendry, John (2006) 'In the mirror of the market: the disciplinary effects of company/fund manager meetings', Accounting, Organizations and Society 31 (3): 277-294.

Samuelson, Paul (1965) 'Proof that properly anticipated prices fluctuate randomly', Industrial Management Review 6 (2): 41-50. 
Sassen, Saskia (2005) 'The embeddedness of electronic markets: the case of global capital markets', in Karin Knorr Cetina and Alex Preda (eds.) The Sociology of Financial Markets, Oxford: Oxford University Press, pp. 17-37.

Sharpe, William (1963) 'A simplified model for portfolio analysis', Management Science 9 (2): 277-293.

(1970) Portfolio Theory and Capital Markets, New York: McGrawHill.

Shiller, Robert (2000) Irrational Exuberance, Princeton, NJ: Princeton University Press.

Sievers, Burkard (1999) 'Psychotic organization as a metaphoric frame for the socioanalysis of organizational and interorganizational dynamics', Administration and Society 31 (5): 588-615.

Steinherr, Alfred (2000) Derivatives: The Wild Beast of Finance, paperback edition, Chichester: John Wiley and Sons.

Thornburg, Steven and Roberts, Robin (2008) 'Money, politics, and the regulation of public accounting services: evidence from the Sarbanes-Oxley Act of 2002', Accounting, Organizations and Society 33 (2/3): 229-248.

Thrift, Nigel (1998) 'Virtual capitalism: the globalisation of reflexive business knowledge', in James Carrier and Daniel Miller (eds.) Virtualism: A New Political Economy, Oxford: Berg, pp. 161-186.

Tobin, James (1958) 'Liquidity preference as behavior toward risk', Review of Economic Studies 67 (1): 65-86.

Trinkaus, John and Giacalone, Joseph (2005) 'The silence of the stakeholders: zero decibel level at Enron', Journal of Business Ethics 58 (1): 237-248. 
Watson, Matthew (2007) The Political Economy of International Capital Mobility, Basingstoke: Palgrave Macmillan.

Wolfe, Donald (1988) 'Is there integrity in the bottomline? Managing obstacles to executive integrity', in Suresh Srivastva (ed.) Executive Integrity: The Search for High Human Values in Organizational Life, San Francisco: Jossey-Bass, pp. 140171. 